\title{
Students' academic achievement performance and satisfaction in a flipped classroom in Saudi Arabia
}

\author{
Mahdi M. Alamri \\ College of Education, \\ Education Technology Department, \\ King Faisal University, \\ Alahsa, Saudi Arabia \\ Email: mahdi@kfu.edu.sa
}

\begin{abstract}
This study aimed to investigate the effectiveness of a flipped classroom for students' academic performance and satisfaction. A mixedmethods research design was used to compare the two approaches of a traditional lecture and flipped classroom. Data were gathered via an achievement test, survey questionnaire and interviews, and then analysed. The results indicated a statistically significant difference in students' academic performance for the flipped classroom group. Additionally, almost all students had a high level of satisfaction in the flipped classroom and generally enjoyed learning in the flipped classroom environment. Online materials, peer discussions and the instructor's role were fundamental elements that produced high-quality learning and active learners. However, few students reported some issues that considered as the main obstacles encountered by some students, which were the week computer skills and time-consuming tasks. This study's implications and recommendations for further research are discussed.
\end{abstract}

Keywords: academic achievement performance; satisfaction; flipped classroom; higher education.

Reference to this paper should be made as follows: Alamri, M.M. (2019) 'Students' academic achievement performance and satisfaction in a flipped classroom in Saudi Arabia', Int. J. Technology Enhanced Learning, Vol. 11, No. 1, pp.103-119.

Biographical notes: Mahdi M. Alamri is an assistant professor in Educational Technology department and Vice Dean of Scientific Research Deanship at King Faisal University, Alahsa, Saudi Arabia. He had his PhD degree in Educational Technology from LaTrobe University, Australia, in 2014. He also had his Master degree in Education Technology and his Bachelor degree in Special Education-Gifted and Talented Students' Education from King Saud University, SA, in 2005 and 2001 respectively. His research interests include blended learning, online learning, flipped classroom, social media networks, thinking development skills, problem-based learning and special education programs. 


\section{Introduction}

Recent decades have witnessed tremendous technological advancements, whereby technology has become a powerful tool for individuals, groups and organisations because of its ability to speed up processes, increase efficiency and improve the quality of overall outcomes. However, while the expansion and use of technology across various settings is noteworthy, concerns have been raised about the continual reliance on traditional lecturebased teaching approaches in higher education (Butt, 2014; Hargrove and Nietfeld, 2015; Onsman, 2011). Hargrove and Nietfeld (2015) cautioned that overemphasis on the use of traditional teaching strategies has the potential to impede the development of higherorder thinking skills, which is a critical task for higher learning institutions in the current ever-changing digital world. It has been argued that this presents a great challenge for the higher education system, particularly in terms of its ability to adequately prepare learners to meet the demands of the twenty-first century (McLaughlin et al., 2013). In light of this challenge, scholars have advocated for 'carefully designed interventions' that are tailored to students' specific needs to promote meaningful learning (Hargrove and Nietfeld, 2015, p.293). Flipped classrooms have been one such intervention, which can transform higher education and enhance high-order thinking skills among students in institutions of higher learning (Bergmann and Sams, 2012). Therefore, this study aims to explore the efficacy of flipped classrooms for enhancing students' academic achievement and overall satisfaction.

\section{Theoretical background}

There is compelling empirical and theoretical evidence supporting the motivational and cognitive benefits of collaborative learning, compared with the individualistic and competitive learning that is synonymous with traditional classrooms. According to Stahl (2012), collaborative learning allows students to complete tasks together, which encourages sharing and subsequently improves the learning process. While the potential benefits of collaborative learning have been widely articulated, the major barrier to effective implementation of this approach in the contemporary classroom - as cited by Wagner et al. (2013) - is the lack of time, as perceived by the majority of teachers. However, the flipped classroom model allows teachers to use their time more optimally by removing much of the learning instruction from the class and focusing more on enhancing collaborative learning experiences (Bergmann and Sams, 2012; Songhao et al., 2011).

In a flipped classroom, many of the pre-class activities are 'traditional', while the inclass activities are based on constructivist principles. In comparing the differences between constructivist and traditional classrooms, Brooks and Brooks (1999, p.51) noted that traditional classrooms uphold strict adherence to a fixed standard curriculum, where students are considered 'blank sheets' to be filled by the teacher, and primarily work alone to complete assigned tasks. In contrast, in constructivist classrooms, students' input is highly valued, and they are regarded as 'thinkers' through developing theory about the world. In addition, in a constructivist classroom, students spend much of class time working in groups (Brooks and Brooks, 1999), discussing ideas and the information read and learnt from online materials provided by the teachers. Students play three different roles in constructivism: the social, active and creative learner (Milbrandt et al., 2004). 
Both Piaget and Dewey asserted that the experience of 'puzzlement' or cognitive conflict plays a crucial role in the creation of knowledge (Stone, 2012). As stated by Stone (2012), the flipped classroom is based on both Dewey and Piaget's models of active learning, where it is hypothesised that learning is effective when the learner acts on ideas, rather than merely copying them. It supports the dissemination of knowledge outside assigned class time, so that the social, active and creative student can experience 'puzzlement' in a cooperative and controlled learning environment.

In a constructivist classroom, instruction heavily relies on the use of engaging and manipulative learning materials, rather than the workbooks and textbooks that are synonymous with traditional classrooms (Stahl, 2012). The evaluation of student learning is entwined with teaching and occurs through student exhibitions and observations guided by the teacher. Further, students complete tasks in groups, rather than undertaking them on their own (Findlay-Thompson and Mombourquette, 2014; Strayer, 2012). In the present study, a flipped-format course in education technology was taught to selected students, while another section of students was engaged in a traditional lecture with the same course content.

\subsection{Flipped classroom}

The concept of the flipped classroom dates back to 1982, when Baker envisaged the use of technology to cover learning materials outside of class. In 1995, Baker's (2011) vision was realised, as he placed lecture notes online and encouraged his students to retrieve and use them to improve their learning. The same learning approach was designed and implemented by Lage et al. (2000, p.32) in their 'inverted classroom' model, where learning activities that traditionally occurred inside the classroom were taken outside, and vice-versa. Most recently, the concept has been employed (Pink, 2010), which has been underpinned by the Khan Academy - a renowned online respiratory with over 1500 videos on various topics (Tucker, 2012). The Khan online library offers a support and interactive learning environment where teachers assign direct instructions to their students to be accomplished outside of class.

There is no single and independent definition of a flipped classroom (Street et al., 2015). In the majority of available literature, the concept of a flipped classroom is characterised by pre-class and post-class activities. In-class activities focus on peer learning, active learning and problem solving; a change in the use of classroom and outof-class time; and, most importantly, the use of video technology in teaching (Abeysekera and Dawson, 2015; DeLozier and Rhodes, 2017). According to Strayer (2012, p.172), a 'flipped classroom integrates the regular and systematic use of interactive technologies in the learning process'. Further, according to Bishop and Verleger (2013, p.2), a flipped classroom is 'a new pedagogical method, which employs asynchronous video lectures and practice problems as homework, and active, groupbased problem-solving activities in the classroom'. One of the primary advantages of the flipped classroom is that it engages a diverse group of learners and is not restricted to a specific content area or curriculum (Bergmann and Sams, 2012).

The flipped classroom can assume different forms. For example, one approach to a flipped classroom involves the instructor employing a podcast to teach students about specific concepts of a given topic area as part of their home assignment (Tune et al., 2013). During the actual learning session, the teacher may act as a facilitator of the students, who may be required to use the knowledge gained through completing their 
home assignment to solve a range of assigned activities. These activities may be assigned and completed in small groups, as part of encouraging peer learning. In addition, the teacher may apply a 'just-in-time' teaching approach, where he or she designs class instruction derived from web-guided questions before class (Sharma et al., 2014). Electronic content dissemination in a flipped classroom is not only restricted to audio and video, but also involves the use of presentations and animated interactive simulations (Davies et al., 2013; Street et al., 2015). Despite the varied definitions, the main goal of the flipped classroom is to foster an active learning environment, where students are encouraged to participate in the learning process during class sessions, while ensuring content coverage.

The current study examined previous research investigating the efficacy of flipped classrooms in higher education (Al-Zahrani, 2015; Butt, 2014; Chun and Heo, 2018; El-Banna et al., 2017; Findlay-Thompson and Mombourquette, 2014; Pellas, 2018; Thai et al., 2017; Tune et al., 2013). The majority of these studies indicated positive results, with learners in flipped classrooms found to be more engaged, excited and satisfied (Butt, 2014; Davies et al., 2013; Pellas, 2018), as well as better prepared prior to traditional classroom activities (Tune et al., 2013), and attaining higher scores in examinations (Al-Zahrani, 2015; Chun and Heo, 2018; El-Banna et al., 2017; FindlayThompson and Mombourquette, 2014; Pellas, 2018; Thai et al., 2017; Tune et al., 2013).

\subsection{Academic achievement performance}

Academic achievement is a representation of performance outcomes that indicate the level to which the student has attained specific learning goals (Ali et al., 2013) and demonstrates competence in extracurricular activities (Steinmayr et al., 2014). Bloom's (1956) taxonomy is one of the oldest and most familiar taxonomies for identifying the quality of learning outcomes (Munzenmaier and Rubin, 2013). This taxonomy describes the major areas that comprise lower-order (knowledge, comprehension, application) and higher-order (analysing, synthesis, evaluation) thinking skills (Brown, 2004). In the present study, students' academic achievement performance was investigated by questions designed based on Bloom's taxonomy categories. Exam and assignment scores were used to evaluate students' academic achievement performance.

\subsection{Student satisfaction}

Student satisfaction is regarded an important factor in evaluating the learning programs overall success, as well as an essential factor in measuring the learning approach quality employed by educators (Fulfors, 2013). According to Uka (2014), student satisfaction can generally be defined as the extent to which students achieve the desired academic outcomes and experiences associated with education. It refers to the level at which students meet their academic goals and demonstrate the knowledge gained throughout the learning period (Uka, 2014). For educators, student satisfaction concerns the ability to meet student needs and demands accordingly. Student satisfaction is an important concept because it tends to influence students' motivation, which is crucial to student success. A variety of factors influence student satisfaction, including the quality of the learning course offered, effectiveness of the learning instruction, mode of instruction dissemination, and focus on students' demands and needs, among others. In regard to the current topic, student satisfaction may relate to a range of factors, including the ability to 
provide an engaging learning environment that encourages student participation, with the aim of achieving academic performance and improved student satisfaction (Whittle et al., 2010). It involves implementing a flipped classroom, where students are encouraged to explore different interactive and collaborative learning activities that may have the positive outcomes of improving their academic achievement performance and overall level of satisfaction.

\section{Research questions and definition of terms}

\subsection{Research questions}

The key research questions are as follows:

1 To what extent do flipped classrooms affect students' academic achievement outcomes?

2 Does student participation in flipped classroom activities increase their engagement, enjoyment and satisfaction in relation to learning?

3 What are students' views and perceptions about the flipped classroom model in terms of its perceived benefits and associated challenges?

\subsection{Definition of terms}

- Academic achievement performance: performance outcomes that indicate the level to which the student has attained specific learning goals (Ali et al., 2013).

- Satisfaction: the fulfilment of one's needs, wishes and expectations.

- Flipped classroom: the use of interactive technologies, especially video lectures, during the learning process (Bishop and Verleger, 2013).

- Higher education: a tertiary level of education that occurs after the completion of secondary school education and is often offered in colleges, universities, seminaries and other institutes.

\section{Method}

\subsection{Participants}

The aim of this study was to investigate the effectiveness of flipped classrooms in enhancing students' achievement performance and overall satisfaction. Two groups of students were taught a course in education technology: the flipped classroom (experimental) and traditional (control) groups. The course selected for this study was one of the compulsory subjects in an education college that must be taken by all students in the college. Therefore, participants in this course were from different disciplines and different university levels. The course aims to address several aspects of education technologies, such as concepts of education technology, the importance of educational aids in the learning process, categories of educational means, information and 
communication technology and its elements, the objectives of the Learning Resources Centre and its roles in educational administration, the standards of informatics education, the concept of the computer and its features in education, multimedia, the internet, the concepts and features of e-learning environments, and the application of educational technologies in learning.

Both groups were given the same course syllables and content. However, the experimental group was taught using pre-class activities that included audio/video lectures, notes and slides that were uploaded online. These materials exposed the learners to key concepts prior to class sessions and played an essential role in encouraging them to be responsible learners. The students were able to view and conceptualise key concepts and internalise them into more comprehensible portions at their own learning pace. The in-class learning activities focused on peer discussion, problem solving and effective feedback. The activities were intended to increase students' overall academic achievement performance and level of satisfaction during learning. The students were evaluated using questions prior to the in-class learning activities to ensure they had gained a complete understanding of the course concepts. Students who demonstrated difficulties in understanding the topic were engaged in individual learning activities to help enhance their understanding. The students were also assigned critical activities that encouraged participation, interaction, sharing of information and problem solving. The instructor's role in increasing the students' understanding was central to the learning process. The instructor designed tasks tailored to the students' needs and intervened appropriately during the learning process.

The participants in the current study were randomly selected and divided into two groups. Invitations were sent to the colleges' departments that provide compulsory courses for college students in order to select two classes from the same course. However, the only response received was from the education technologies department, which assigned a course that had several classes. The small number of students engaged in some classes (fewer than 10 students) were excluded, and only classes with a large number of students were selected and invited to participate voluntarily in the current study. The flipped classroom group consisted of 26 students, and the control group consisted of 26 students who were taught using the traditional lecture-based approach. The students in the control group attended traditional lectures, where they were provided with written notes, presentations and assigned activities to complete on their own as part of their homework. The control and experimental groups that participated in this study comprised undergraduate male students who were demographically and academically equivalent in terms of age, university levels, grade point average, course type, computer ownership at home, internet access and years of computer usage. ${ }^{1}$

\subsection{Data sources and analysis}

\subsubsection{Academic achievement test}

To measure the effects of learning in a flipped classroom environment on students' academic performance, the exam and assignment scores of students in the experimental group were compared with those of the control group. The content and learning objectives of computer applications in the education course delivered to the students were the same, and only differed in terms of the mode of delivery, whereby a 
flipped-format course was administered to the experimental group, and a traditional lecture approach was delivered to the control group. Both groups of students were exposed to computer applications in the education course content for a period of 10 weeks. In the flipped classroom model, the students were provided with online course materials that included audio/video lectures, extensive notes, online assignments and presentations. They were also involved in peer discussions and problem-solving activities. In contrast, in the traditional lecture, learning was based on the student textbooks, aided with teacher-created activities to demonstrate the students' understanding of the concepts. Within the period of this research, the students were offered two sets of quiz exams that were conducted at a five-week interval to measure the students' academic performance throughout the semester.

\subsubsection{Satisfaction questionnaire}

A questionnaire was designed to collect data about the students' level of satisfaction with the flipped classroom model, and whether they enjoyed learning in the flipped classroom environment. The respondents' level of satisfaction was measured using a five-point Likert scale (ranging from $5=$ 'very satisfied' to $1=$ 'very dissatisfied'). The questionnaire was divided into three different sections. The first section collected the students' demographic information. The second section gathered the students' level of satisfaction with the flipped classroom environment. The third section consisted of openended questions, where the respondents provided suggestions regarding the adoption of a flipped learning model at the college.

\subsubsection{One-on-one interviews}

This study also involved one-on-one interviews. Voluntary participants were queried about the effectiveness of flipped classrooms, compared with the traditional lecture-based teaching approach, and whether the flipped classroom model increased their understanding of the subject matter. The interviews aimed to collect information about the students' level of satisfaction with the flipped classroom environment. As noted by Shadish et al. (2012), the main goal of one-on-one interviews is to access an accurate and rich source of data on participants' perspectives, insights and opinions on their everyday experiences. Interviews also allow the researcher to extract information from the participants that is crucial to answer the research questions, which may be otherwise difficult to obtain through other data collection methods. Using one-on-one interviews to capture the students' views on learning in a flipped classroom environment, compared with the traditional classroom setting, offered a crucial source of data for this study.

\subsection{Procedures}

The data from the student academic achievement test scores and questionnaires were analysed using the Software Package for Social Sciences (SPSS). The SPSS application was used because of its ability to provide accurate statistical information in various formats, such as tables, percentages and graphs, which allows for easier analysis (Pallant, 2007). The responses from the participants on the academic achievement test were coded and analysed using an independent sample $t$-test to identify the mean scores and statistical differences across the control and experimental groups (Patton, 2009). 
Descriptive statistics, including frequencies, were also generated to compare levels of satisfaction regarding the flipped classroom. In addition, Cohen's $d$ effect size estimates were produced to help understand the standardised difference between variables and means (Cohen, 1988; Creswell, 2010). Moreover, the data gathered from the one-on-one interviews were qualitatively analysed and discussed.

\section{Results}

\subsection{Students' academic achievement}

The students' academic achievements were compared between the control and experimental groups to determine any statistical differences. The data collected were analysed using SPSS 22.0. The percentage of data can be seen as follows.

Table 1 Distribution analysis of data measured in post-test

\begin{tabular}{lccc}
\hline & Mean & Standard Deviation $(S D)$ & Variance \\
\hline Experimental Group & 23.77 & 2.930 & 8.585 \\
Control Group & 21.62 & 3.112 & 9.686 \\
\hline
\end{tabular}

Based on Table 1, the mean score of the students in the experimental group (23.77, $S D=2.930)$ was higher than that of the control group $(21.62, S D=3.112)$. The interval of the mean between the experimental and control group was 2.15. This result indicated that the different treatments given to the experimental and control group had a significant effect on the result of the mean. Additionally, the $S D$ of the experimental group was 2.930 , while the $S D$ of the control group was 3.112. This result indicated that the experimental group had a lower $S D$ than did the control group, which demonstrated that the mean of the students taught through flipped learning was better in describing all scores. The mean of the experimental group was more representative than the mean of the control group. The Cohen's $d$ effect size estimate of .335 indicated that the practical significance of the score differences was small to medium in magnitude (Cohen, 1992).

Hypothesis testing was administered using inferential statistical analysis. Hypothesis testing using an independent sample test ( $t$-test) was conducted to determine whether there was a significant difference in achievement between the students taught using a flipped classroom and students taught using conventional media. The results of the data were calculated using SPSS 22.0 at a $5 \%$ level of significance. There were two qualifications to determine whether the hypothesis was rejected. If $t_{c v}$ ( $t$-critical value) was lower than $t_{o b s}(t$ observed), the null hypothesis would be rejected and alternative hypothesis accepted. In contrast, if $t_{c v}$ was more than $t_{o b s}$, the null hypothesis would be accepted and alternative hypothesis rejected. Table 2 presents the results of the independent sample test ( $t$-test).

Table 2 displays that the value of Sig. (2-tailed) was 0.013 , which indicates that the observed level of significance (Sig. [2-tailed]) was less than the standard alpha level $(\alpha=0.05)$. After determining the result, the hypothesis testing was analysed in terms of $t_{o b s}$ and $t_{c v}$. To analyse the $t$-test, the value of $t_{o b s}$ was compared with $t_{c v}$ to measure whether the mean scores of the two groups were significantly different. In addition, for the equal variances assumed, $t_{o b s}$ was 2.569. Based on Table 2, the $t$-critical value for degrees of freedom $(d f) 50$ was 2.0086. Therefore, the comparison between $t_{o b s}$ and $t_{c v}$ 
was $2.569>2.0086$ because the value of $t_{o b s}$ was higher than that of $t_{c v}$. Thus, the null hypothesis $\left(\mathrm{H}_{0}\right)$ was rejected and alternative hypothesis $(\mathrm{H} \alpha)$ was accepted. Consequently, it could be concluded that there was a significant effect of using a flipped classroom in terms of student achievement, and the students in the experimental group demonstrated better performance than did the control group in terms of student achievement.

Table 2 Results of independent sample test ( $t$-test)

\begin{tabular}{|c|c|c|c|c|c|c|c|c|c|c|}
\hline & & $\begin{array}{r}\text { Leve } \\
\text { test } \\
\text { equat } \\
\text { varic }\end{array}$ & $\begin{array}{l}\text { ne's } \\
\text { for } \\
\text { ity of } \\
\text { inces }\end{array}$ & & & t-test fo & or equality $o$ & of means & & \\
\hline & & $F$ & Sig. & $T$ & $d f$ & $\underset{\text { (2-tailed) }}{\text { Sig. }}$ & $\begin{array}{c}\text { Mean } \\
\text { difference }\end{array}$ & $\begin{array}{l}\text { Std error } \\
\text { difference }\end{array}$ & $\begin{array}{r}95 \% \text { co } \\
\text { inter } \\
\text { diffe } \\
\end{array}$ & $\begin{array}{l}\text { nfidence } \\
\text { val of } \\
\text { rence }\end{array}$ \\
\hline & & & & & & & & & Lower & Upper \\
\hline & $\begin{array}{l}\text { Equal } \\
\text { variances } \\
\text { assumed }\end{array}$ & .119 & .732 & -2.569 & 50 & .013 & -2.154 & .838 & -3.838 & -.470 \\
\hline Score & $\begin{array}{l}\text { Equal } \\
\text { variances } \\
\text { not } \\
\text { assumed }\end{array}$ & & & -2.569 & 49.819 & .013 & -2.154 & .838 & -3.838 & -.470 \\
\hline
\end{tabular}

\subsection{Students' satisfaction with flipped classroom}

A questionnaire was provided to investigate students' satisfaction with the flipped classroom. The 26 students in the flipped classroom course responded to the questionnaire. Table 3 presents the main section of the questionnaire that included the participants' views on the flipped classroom.

Table 3 Participants' satisfaction with flipped classroom $(n=26)$

\begin{tabular}{lccccccc}
\hline Statement & $\begin{array}{c}\text { Strongly } \\
\text { agree (\%) }\end{array}$ & $\begin{array}{c}\text { Agree } \\
(\%)\end{array}$ & $\begin{array}{c}\text { Unsure } \\
(\%)\end{array}$ & $\begin{array}{c}\text { Disagree } \\
(\%)\end{array}$ & Mean & $S D$ \\
\hline $\begin{array}{l}\text { I was able to learn from the course materials } \\
\text { in the flipped classroom }\end{array}$ & 42.3 & 46.2 & 11.5 & 0 & 4.31 & .68 \\
\hline $\begin{array}{l}\text { I was stimulated to complete additional } \\
\text { readings or research on topics discussed in } \\
\text { the course }\end{array}$ & 46.2 & 53.8 & 0 & 0 & 4.46 & .51 \\
\hline $\begin{array}{l}\text { Discussions in the flipped classroom assisted } \\
\text { me in understanding other points of view }\end{array}$ & 42.3 & 46.2 & 11.5 & 0 & 4.31 & .68 \\
\hline $\begin{array}{l}\text { As a result of my experience with this course, } \\
\text { I would like to take another flipped classroom } \\
\text { course in the future }\end{array}$ & 80.8 & 19.2 & 0 & 0 & 4.81 & .40 \\
\hline $\begin{array}{l}\text { This course in the flipped classroom was a } \\
\text { useful learning experience }\end{array}$ & 65.4 & 34.6 & 0 & 0 & 4.65 & .49 \\
\hline
\end{tabular}


Table 3 Participants' satisfaction with flipped classroom $(n=26)$ (continued)

\begin{tabular}{lccccccc}
\hline Statement & $\begin{array}{c}\text { Strongly } \\
\text { agree (\%) }\end{array}$ & $\begin{array}{c}\text { Agree } \\
(\%)\end{array}$ & $\begin{array}{c}\text { Unsure } \\
(\%)\end{array}$ & $\begin{array}{c}\text { Disagree } \\
\text { (\%) }\end{array}$ & Mean & $S D$ \\
\hline $\begin{array}{l}\text { The diversity of topics and resources in this } \\
\text { course prompted me to participate effectively } \\
\text { in discussions }\end{array}$ & 65.4 & 34.6 & 0 & 0 & 4.65 & .49 \\
\hline $\begin{array}{l}\text { I invested a great deal of effort to search } \\
\text { about topics on the internet to increase my } \\
\text { participation in this course }\end{array}$ & 38.5 & 50 & 11.5 & 0 & 4.27 & .67 \\
\hline $\begin{array}{l}\text { My level of learning that occurred in this } \\
\text { course was of the highest quality }\end{array}$ & 50 & 38.5 & 11.5 & 0 & 4.38 & .70 \\
\hline $\begin{array}{l}\text { The learning activities and assignments of } \\
\text { this course met my learning expectations }\end{array}$ & 53.8 & 46.2 & 0 & 0 & 4.54 & .51 \\
\hline $\begin{array}{l}\text { The instructor for this course met my learning } \\
\text { expectations }\end{array}$ & 73.1 & 26.9 & 0 & 0 & 4.73 & .45 \\
\hline $\begin{array}{l}\text { This flipped classroom course met my } \\
\text { learning expectations }\end{array}$ & 57.7 & 42.3 & 0 & 0 & 4.58 & .50 \\
\hline $\begin{array}{l}\text { The flipped classroom helped me learn more } \\
\text { than I would have if we had completed } \\
\text { traditional lessons }\end{array}$ & 53.8 & 46.2 & 0 & 0 & 4.54 & .51 \\
\hline $\begin{array}{l}\text { I found it easy to pace myself successfully } \\
\text { through this course }\end{array}$ & 30.8 & 57.7 & 3.8 & 7.7 & 4.12 & .82 \\
\hline $\begin{array}{l}\text { The flipped classroom has improved my } \\
\text { learning outcomes }\end{array}$ & 57.7 & 38.5 & 3.8 & 0 & 4.54 & .58 \\
\hline
\end{tabular}

As presented in Table 3, most participants (88\%) agreed that they were able to learn from the course materials in the flipped classroom, and that discussions during class helped them understand other perspectives $(M=4.31, S D=.68)$, while only $12 \%$ of participants were unsure. In addition to holding a positive perception of the implementation of the flipped classroom, the students were highly motivated in this class. Most students $(88 \%)$ answered that they invested a great deal of effort to search for topics on the internet $(M=4.46, S D=.51)$ to increase their participation in this course $(M=4.27, S D=.67)$, while only $12 \%$ were unsure about this item. In addition, $88 \%$ of students stated that their level of learning in the flipped classroom was of the highest quality $(M=4.38$, $S D=.70)$

Moreover, it can be seen that the participants had a positive response towards the implementation of the flipped classroom, as proven by their responses to several questions. For example, all students $(100 \%)$ agreed that they wished to take another flipped classroom course in the future $(M=4.81, S D=.40)$ because they had useful learning experiences $(M=4.65, S D=.49)$ that made them willing to participate effectively in classroom discussions $(M=4.65, S D=.49)$. Additionally, most students stated that the flipped classroom met their expectation in terms of learning activities and assignments $(M=4.54, S D=.51)$, the instructor $(M=4.73, S D=.45)$ and their learning $(M=4.58, S D=.50)$. Given that the students' expectations were fulfilled, the learning environment became more engaging, enjoyable and helpful than the traditional classroom. As a result, most students felt that the implementation of the flipped 
classroom helped them succeed $(M=4.12, S D=.82)$ and improved their learning outcomes $(M=4.54, S D=.58)$, although some students $(8 \%)$ did not agree with this (Item 13).

Overall, the findings of the study suggest that the students favoured learning in a flipped classroom over a traditional lecture-based classroom $(M=4.54, S D=.51)$. In the questionnaire, the students were asked to subjectively rate the flipped and traditional teaching methods in terms of their effectiveness to increase mastery of the course material. The majority of students showed greater preference for the flipped classroom, rather than traditional lectures. Interestingly, almost all students had a high level of satisfaction in the flipped classroom and generally enjoyed learning in the flipped classroom environment. Additionally, the students revealed that the positive performance and outcomes were a result of learning through this flipped course. Online course materials, effective peer discussions and the instructor's role were fundamental elements that produced a high quality of learning and active learners (items 1, 3 and 10 respectively).

\subsection{Student interviews}

One-on-one interviews were conducted to clarify, understand and explore the results gained from the students' academic performance and questionnaire. Nine students voluntarily participated in the interviews, and were asked to describe their experiences in the flipped classroom. These participants discussed several elements of the flipped classroom environment that enhanced their learning: online course materials, effective peer discussions and the instructor's role. The online materials helped the students cover the lesson content and prepared them for the class discussions before they attended the real class. The materials also encouraged the students to read more about the topic from a variety of online sources to expand their understanding and actively participate in the class discussions. Interviewees B and D stated the following:

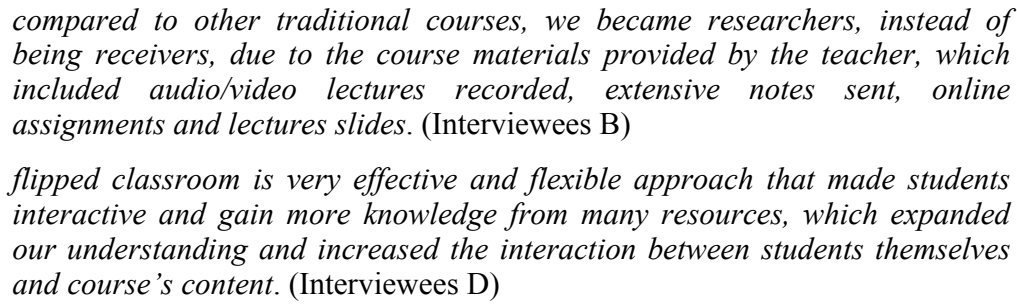

flipped classroom is very effective and flexible approach that made students interactive and gain more knowledge from many resources, which expanded our understanding and increased the interaction between students themselves and course's content. (Interviewees D)

Additionally, the online course materials enabled the students to learn at a convenient time and place, particularly for those who could not attend the class because of travel or illness. Moreover, students were able to repeat the lesson content many times to gain improved understandings.

The flipped classroom also increased effective peer discussions. This was a result of interactions with each other outside of class time during online discussions, which built strong relationships among the students. This helped eliminate students' fear of talking in front of their peers in the classroom. As Interviewee A stated:

the supportive atmosphere of flipped approach motivated most students to confidently ask questions, debate and support other points of view inside and outside the class. (Interviewees A) 
In addition, student preparation before the class made the students more flexible and willing to learn from other peers to reach to a comprehensive understanding of the topic discussed. As a result of effective peer discussions, the learning in the flipped classroom became more enjoyable, and learners moved from passive to active learners:

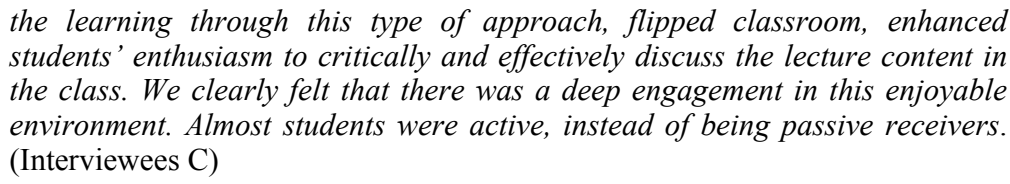

The third element reported was the instructor's role. The instructor was a mentor, guide and facilitator throughout the course, who provided assistance and guidance to all students during the semester, both outside and inside the classroom. This generally supported the learning process and particularly supported students' social and cognitive abilities, which were obvious from their interaction with the course materials and content, as well as their academic performance. Several participants confirmed that:

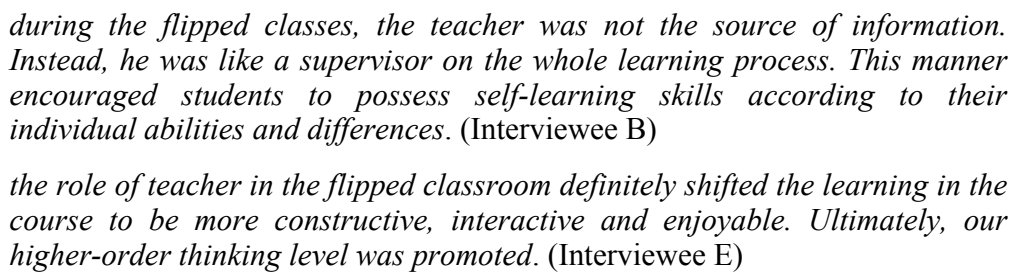

Although most interviewees reported positive comments about the flipped classroom, a few students raised two factors that may have hindered their learning in the flipped classroom. Students' computer skills and time-consuming tasks were the main obstacles encountered by some students. Many tasks in this course had to be completed by students before attending the class, using computers and the internet. Despite all students having computers and access to the internet at home, many students encountered difficulties regarding their computer skills to complete the tasks required. Interviewee $\mathrm{C}$ discussed this issue:

one of the biggest obstacles that faced most students was the lack of experience in using computers and finding information from reliable websites in the World Wide Web. However, they gradually learned how to overcome those issues and developed many technical skills over the time. (Interviewees C)

Moreover, several students found the workload inconvenient for tasks required to be completed at home, such as watching videos, searching for information and completing assignments. They reported that they had to sit in front of computers for long periods to complete the required tasks to prepare themselves for the next class. One interviewee stated that:

although we enjoyed the new experience in the flipped approach, there were a lot of homework compared to other traditional classes. More than two hours a day must be spent for a good preparation to be ready and active in class discussions. (Interviewees $\mathrm{H}$ )

Overall, there was general consistency with the results obtained from the academic achievement test, satisfaction questionnaire and interviews. The interview stage confirmed the positive results of the academic achievement performance and student satisfaction. The participants justified these findings by stating that the online course 
materials, effective peer discussions and instructor's role were crucial elements in motivating them to perform better. They improved their social and cognitive skills to be active senders and receivers of information. Ultimately, the students began to effectively interact with others and critically construct knowledge. However, few students reported some issues that considered as the main obstacles encountered by some students, which were the week computer skills and time-consuming tasks.

\section{Discussion}

The findings suggest that learning in a flipped classroom increases students' academic performance and level of satisfaction, compared with the traditional classroom environment. Despite the limitations regarding the small sample size of undergraduate male students and the nature of the course selected, the findings of this study are consistent with those of other studies that have investigated the efficacy of the flipped approach for enhancing student engagement and increasing understanding of key concepts (Al-Zahrani, 2015; Bergmann and Sams, 2012; Butt, 2014; Chun and Heo, 2018; Davies et al., 2013; El-Banna et al., 2017; Findlay-Thompson and Mombourquette, 2014; McLaughlin et al., 2013; Pellas, 2018; Thai et al., 2017; Tune et al., 2013). Previous studies that investigated the effectiveness of the flipped classroom - such as those of Al-Zahrani (2015) and Wagner et al. (2013) - found that the integration of technology in learning increased student outcomes in terms of enhancing their memory skills, creativity and critical thinking skills. Moreover, Mason et al. (2013) observed that the use of visual tools, such as videos, encouraged the creation of an interactive and engaging learning environment, which led to improved student learning outcomes. In addition, Tune et al. (2013) concluded that the flipped classroom has the potential to enhance the high-order thinking skills of students in higher institutions. However, many prior studies underscored that flipped learning can only be successful when there is effective instructor intervention (Al-Zahrani, 2015; Stone, 2012; Street et al., 2015), which highlights the crucial importance of the instructor's role in a flipped learning environment.

Moreover, while the findings of this study indicated the potential benefits of the flipped classroom in terms of improved academic performance and satisfaction, students' responses suggested that incorporating specific aspects of flipped learning was successful. The students appreciated the quality and variety of pre-class and in-class activities and materials that were offered, as they increased their understanding of key concepts prior to and during classroom sessions. A majority cited that the pre-class activities prepared them for the instruction during the in-class sessions. Others appreciated the effectiveness of peer discussions in increasing their understanding of the subject and developing their social and cognitive skills. This information indicates the need for educators to design flipped classrooms in a manner that is tailored to the specific needs of their students. Offering a variety of quality learning materials and using different modes of delivery can play an essential role in encouraging participation and meeting the learning preferences of students (Mertens, 2005). As noted by Strayer (2012), because the flipped classroom frees up time to allow the use of several learning approaches, it is prudent for educators to explore different teaching approaches, rather than adhering to a single mode of teaching throughout the course. 


\section{Conclusion and recommendations}

While the findings of this study are crucial to indicate the benefits of the flipped classroom in enhancing student performance and satisfaction, the study was impeded by at least three limitations. Given that this was the first time the flipped-course format was introduced to the students, the findings could have been biased, as the students could have held prior knowledge of the intent of the flipped classroom. Moreover, the study focused on a relatively small sample size of undergraduate male students with almost similar demographics, which limits the generalisability of the findings. In addition, because the current study was conducted with a group of students enrolled in one course at an education college titled 'education technology', the results could be varied when flipped approach is used with other courses or disciplines.

In conclusion, the implementation of a flipped-course format in education technology was successful and generally demonstrated improved student academic achievement and satisfaction, compared with the traditional lecture-based approach. However, it is important for future research to examine the efficacy of the flipped classroom with student samples that comprise larger sample sizes and different demographic compositions to shed more light on the success of flipped learning for students in higher education. The participants in the current study were male undergraduate students in Saudi Arabia. Similar studies should include female students in other places and contexts.

Moreover, the positive results from this study may be different when a flipped approach is conducted on courses from other disciplines. Thus, more practical research is needed to contribute a deeper understanding of the effectiveness of the flipped approach in enhancing students' learning outcomes in other courses at university colleges. Subsequent studies should be conducted to investigate the absence of such active approaches and effective practices in global higher education institutions.

\section{Acknowledgement}

The author acknowledges the Deanship of Scientific Research at King Faisal University for the financial support under grant (186003).

\section{References}

Abeysekera, L. and Dawson, P. (2015) 'Motivation and cognitive load in the flipped classroom: definition, rationale and a call for research', Higher Education Research \& Development, Vol. 34, No. 1, pp.1-14.

Ali, S., Haider, Z., Munir, F., Khan, H. and Ahmed, A. (2013) 'Factors contributing to the students' academic performance: a case study of Islamia University sub-campus', American Journal of Educational Research, Vol. 1, No. 8, pp.283-289.

Al-Zahrani, A.M. (2015) 'From passive to active: the impact of the flipped classroom through social learning platforms on higher education students' creative thinking', British Journal of Educational Technology, Vol. 46, No. 6, pp.1134-1150. 
Baker, J.W. (2011) The Origins of the Classroom Flip, Unpublished manuscript, Department of Media \& Applied Communications, Cedarville University, Cedarville, $\mathrm{OH}$.

Bergmann, J. and Sams, A. (2012) Flip Your Classroom: Reach Every Student in Every Class Every Day, International Society for Technology in Education, Washington, DC.

Bishop, J.L. and Verleger, M.A. (2013) 'The flipped classroom: a survey of the research', Paper presented at the 120th ASEE Conference \& Exposition, 23-26 June, Atlanta, GA, Vol. 30, No. 9, pp.1-18.

Bloom, B.S. (1956) Taxonomy of Educational Objectives, Handbook I: The Cognitive Domain, David McKay Co Inc., New York.

Brooks, J.G. and Brooks, M.G. (1999) In Search of Understanding: The Case for Constructivist Classrooms, Association for Supervision and Curriculum Development, Alexandria, VA.

Brown, T. (2004) 'Bloom's taxonomy', in Kincheloe, J.L. and Weil, D. (Eds): Critical Thinking and Learning: An Encyclopedia for Parents and Teachers, Greenwood Press, London, pp.77-82.

Butt, A. (2014) 'Student views on the use of a flipped classroom approach: evidence from Australia', Business Education \& Accreditation, Vol. 6, No. 1, pp.33-43.

Chun, B. and Heo, H.J. (2018) 'The effect of flipped learning on academic performance as an innovative method for overcoming Ebbinghaus' forgetting curve', Proceedings of the 6th International Conference on Information and Education Technology, 6-8 January, ACM, Osaka, Japan, pp.56-60.

Cohen, J. (1988) Statistical Power Analysis for the Behavioral Sciences, 2nd ed., Lawrence Earlbaum Associates, Hillsdale, NJ.

Cohen, J. (1992) 'A power primer', Psychological Bulletin, Vol. 112, No. 1, p.155.

Creswell, J.W. (2010) Educational Research: Planning, Conducting, and Evaluating Quantitative and Qualitative Research, 4th ed., Pearson, New Jersey.

Davies, R.S., Dean, D.L. and Ball, N. (2013) 'Flipping the classroom and instructional technology integration in a college-level information systems spreadsheet course', Educational Technology Research and Development, Vol. 61, No. 4, pp.563-580.

DeLozier, S.J. and Rhodes, M.G. (2017) 'Flipped classrooms: a review of key ideas and recommendations for practice', Educational Psychology Review, Vol. 29, No. 1, pp.141-151.

El-Banna, M.M., Whitlow, M. and McNelis, A.M. (2017) 'Flipping around the classroom: accelerated Bachelor of Science in nursing students' satisfaction and achievement', Nurse Education Today, Vol. 56, pp.41-46.

Findlay-Thompson, S. and Mombourquette, P. (2014) 'Evaluation of a flipped classroom in an undergraduate business course', Business Education \& Accreditation, Vol. 6, No. 1, pp.63-71.

Fulfors, A. (2013) 'Satisfaction, settlement and exposition: conversation and the university tutorial', Ethics and Education, Vol. 8, No. 2, pp.114-122.

Hargrove, R.A. and Nietfeld, J.L. (2015) 'The impact of metacognitive instruction on creative problem solving', The Journal of Experimental Education, Vol. 83, No. 3, pp.291-318.

Lage, M., Platt, G. and Treglia, M. (2000) 'Inverting the classroom: a gateway to creating an inclusive learning environment', Journal of Economic Education, Vol. 31, No. 1, pp.30-43.

Mason, G.S., Shuman, T.R. and Cook, K.E. (2013) 'Comparing the effectiveness of an inverted classroom to a traditional classroom in an upper-division engineering course', IEEE Transactions on Education, Vol. 56, No. 4, pp.430-435.

McLaughlin, J.E., Griffin, L.M., Esserman, D.A. et al. (2013) 'Pharmacy student engagement, performance, and perception in a flipped satellite classroom', American Journal of Pharmaceutical Education, Vol. 77, No. 9, pp.1-8. 
Mertens, D.M. (2005) Research and Evaluation in Education and Psychology: Integrating Diversity with Quantitative, Qualitative, and Mixed Methods, 2nd ed., Sage Publications, Thousand Oaks, CA.

Milbrandt, M.F., Felts, J., Richards, B. and Abghari, N. (2004) 'Teaching-to-learn: a constructivist approach to shared responsibility', Art Education, Vol. 57, No. 5, pp.19-33.

Munzenmaier, C. and Rubin, N. (2013) 'Bloom's taxonomy: what's old is new again', The eLearning Guild Research, Vol. 19, No. 2, pp.1-15.

Onsman, A. (2011) 'It is better to light a candle than to ban the darkness: government led academic development in Saudi Arabian universities', Higher Education, Vol. 62, No. 4, pp.519-532.

Pallant, J.F. (2007) SPSS Survival Manual: A Step by Step Guide to Data Analysis Using SPSS, 3rd ed., Allen \& Unwin, Crows Nest, NSW.

Patton, M.Q. (2009) Qualitative Research \& Evaluation Methods, 5th ed., Sage, Thousand Oaks, CA.

Pellas, N. (2018) 'Can the flipped classroom model improve students' academic performance and training satisfaction in higher education instructional media design courses?', Bepress, University of the Aegean, 23 August, pp.1-27.

Pink, D. (2010) 'Think tank: flip-thinking - the new buzz word sweeping the US', The Telegraph. Available online at: http://www.telegraph.co.uk/finance /businessclub/7996379/Daniel-PinksThink-Tank-Flip-thinking-the-new-buzz-word-sweeping-the-US.html (accessed on 28 January 2018).

Shadish, W.R., Cook, T.D. and Campbell, D.T. (2012) Experimental and Quasi-experimental Designs for Generalized Causal Inference, Houghton Mifflin, Boston, MA.

Sharma, N., Lau, C.S., Doherty, I. and Harbutt, D. (2014) 'How we flipped the medical classroom', Medical Teacher, Vol. 37, No. 4, pp.327-330.

Songhao, H., Saito, K., Maeda, T. and Kubo, T. (2011) 'Evolution from collaborative learning to symbiotic e-learning: creation of new e-learning environment for knowledge society', Online Submission, Vol. 8, No. 1, pp.46-53. Retrieved from ERIC database (ED519417).

Stahl, G. (2012) 'Theories of collaborative cognition', in Goggins, S. and Jahnke, I. (Eds): CSCL at Work, Springer, New York, pp.1-20. Available online at: http://GerryStahl.net/pub/collab cognition.pdf (accessed on 12 September 2017).

Steinmayr, R., Meißner, A., Weidinger, A.F. and Wirthwein, L. (2014) 'Academic achievement', Oxford Bibliographies. Available online at: http://dx.doi.org/10.1093/obo/97801997568100108 (accessed on 19 December 2017).

Stone, B.B. (2012) 'Flip your classroom to increase active learning and student engagement', Paper presented at the 28th Annual Conference on Distance Teaching \& Learning, May 2012, Madison, WI.

Strayer, J.F. (2012) 'How learning in an inverted classroom influences cooperation, innovation and task orientation', Learning Environments Research, Vol. 15, No. 2, pp.171-193.

Street, S.E., Gilliland, K.O., McNeil, C. and Royal, K. (2015) 'The flipped classroom improved medical student performance and satisfaction in a pre-clinical physiology course', Medical Science Educator, Vol. 25, No. 1, pp.35-43.

Thai, N.T.T., De Wever, B. and Valcke, M. (2017) 'The impact of a flipped classroom design on learning performance in higher education: looking for the best "blend" of lectures and guiding questions with feedback', Computers \& Education, Vol. 107, pp.113-126.

Tucker, B. (2012) 'The flipped classroom: online instruction at home frees class time for learning', Education Next, Vol. 12, No. 1, pp.82-83. Available online at: http://www.msuedtechsand box.com/MAETELy2-2015/wp-content/uploads/2015/07/the flipped_classroom article_2.pdf (accessed on 27 September 2017). 
Tune, J.D., Sturek, M. and Basile, D.P. (2013) 'Flipped classroom model improves graduate student performance in cardiovascular, respiratory, and renal physiology', Advances in Physiology Education, Vol. 37, No. 4, pp.316-320.

Uka, A. (2014) 'Student satisfaction as an indicator of quality in higher education', Journal of Educational and Instructional Studies, Vol. 4, No. 3, pp.6-11.

Wagner, D., Laforge, P. and Cripps, D. (2013) 'Lecture material retention: a first trial report on flipped classroom strategies in electronic systems engineering at the University of Regina', Paper presented at the Canadian Engineering Education Association (CEEA13) Conference, 17-20 June, Canada.

Whittle, S.R., Pell, G. and Murdoch-Eaton, D.G. (2010) 'Recent changes to students' perceptions of their key skills on entry to higher education', Journal of Further and Higher Education, Vol. 34, No. 4, pp.557-570.

\section{Note}

1 Data of the respondents in the flipped classroom is available from the author upon request. 